\title{
A Rare Case of a Gunshot Injury: No Urinary Symptoms with a Voided Bullet
}

\section{Nadir Görülen Bir Silahla Yaralanma Olgusu: Üriner Sistem Semptomu Olmadan işeme Yoluyla Düşürülen Kurşun}

\author{
Yasin Ceylan, Zafer Kozacıoğlu, Volkan Şen, Tansu Değirmenci, İbrahim Küçüktürkmen, \\ Bülent Günlüsoy \\ Izmir Bozyaka Training and Research Hospital, Clinic of Urology, Izmir, Turkey
}

\section{Abstract}

Gunshot injuries to the abdominal cavity are cases of emergency which can be life-threatening depending on the organ/s affected. High-velocity penetrating injuries can cause both a penetrating injury to the organs on its' route or can cause blast injury nearby. In most of the cases, the bullet can be found and the defect can be repaired intraoperatively.

Here, we present a rare case of a patient with an intrabdominal penetrating gunshot wound with no organ injury, including the bladder, who voided the bullet spontaneously 30 days after the injury.

Keywords: Bladder, cystogram, gunshot wound, trauma
Öz

Karın boşluğuna ateşli silah yaralanmaları etkilenen organlara göre hayati tehlike yaratabilen, nadir görülen bir acil başvuru nedenidir. Yüksek hız delici yaralanmalar hizasındaki etkilediği organda penetran yaralanmaya sebep olmakla birlikte, komşu organlarda patlama tarzında yaralanmaya yol açabilmektedir. Olguların çoğunda, mermi bulunabilir ve yaralanma intraoperatif tamir edilebilir.

Karın boşluğuna ateşli silah yaralanması olan, mesane dahil hiç bir organın yaralanmadığı, 30 gün sonra kurşunu spontan olarak işeyen, nadir görülen olgumuzu sunmayı amaçladık.

Anahtar Sözcükler: Mesane, sistogram, ateşli silah yaralanması, travma

\section{Case}

A 30-year-old man was admitted to the emergency room due to a gunshot wound in his right inguinal area with subcutaneous emphysema and edema. No exit wound of the bullet could be demonstrated. Abdominal computed tomography $(\mathrm{CT})$ revealed a high-resolution metal with artifacts posterior to the bladder. The balloon of the Foley catheter was intact with some air in the bladder. Abdominal exploration was indicated and general surgeons explored the rectum, intestines, other intra abdominal organs and the seminal vesicles posterior to the bladder. Upon urologic consultation, bladder was filled with saline and no leak or rupture area could be demonstrated. The bullet could not be found. The patient was discharged with
Address for Correspondence/Yazıșma Adresi: Volkan Şen İzmir Bozyaka Training and Research Hospital, Clinic of Urology, İzmir, Turkey Phone.: +90 2322505050 E-mail: sen_volkan@yahoo.com

Received/Geliş Tarihi: 08 December 2015 Accepted/Kabul Tarihi: 25 December 2015
The Medical Bulletin of Haseki Training and Research Hospital, published by Galenos Publishing. Haseki Tıp Bülteni, Galenos Yayınevi tarafından basılmıştır. 
no hematuria or urologic symptoms on postoperative day nine. One week later, pelvic CT and cystography revealed slight thickening of the bladder wall and the bullet on the left posterolateral aspect of the bladder (Figure 1, 2). Cystography revealed intact bladder wall 30 days later when the patient presented to the outpatient department saying that he has voided the bullet. Pelvic radiographies showed no bullet; and the patient was catheterized for a week due to urinary retention (Figure 3). He experienced no urologic complaints and was discharged one week later.

\section{Discussion}

Perforating injuries to the abdominal cavity are emergency events requiring urgent abdominal exploration.

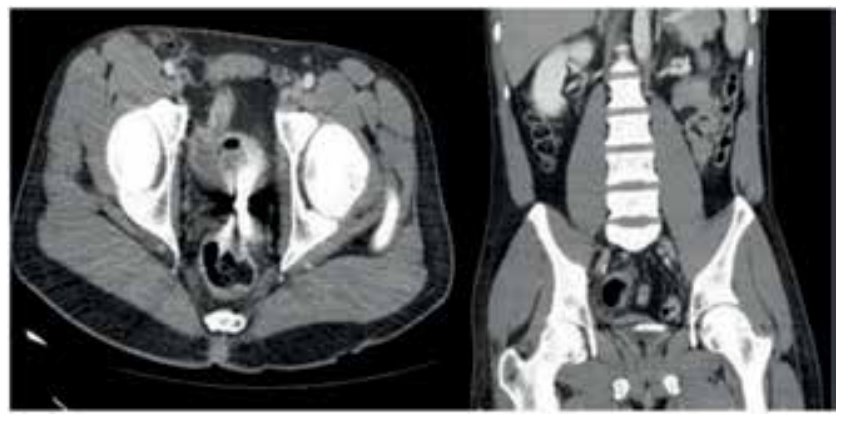

Figure 1. Slight thickening of the bladder wall and the bullet on left posterolateral aspect of the bladder

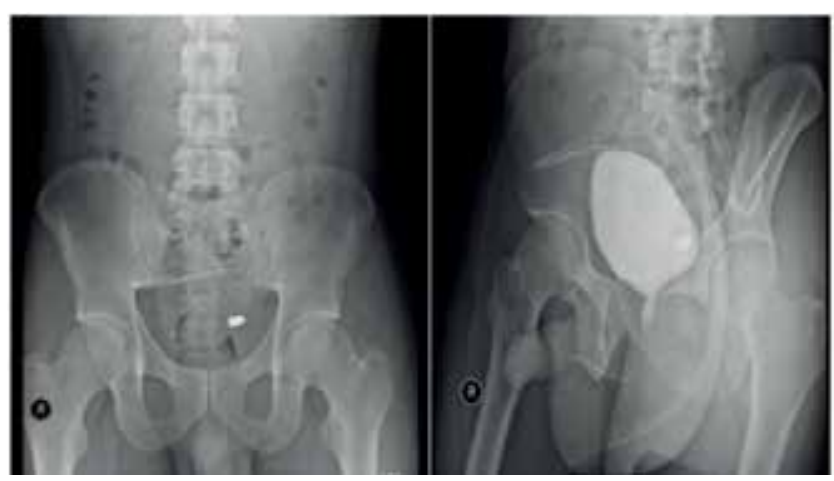

Figure 2. Bullet on left posterolateral aspect of the bladder
Gunshot wounds differ from stab wounds in terms of the consequences they cause due to the blast effect of the highvelocity bullet. Arthurs et al. (1) have reported the most lethal combination of injuries due to penetrating pelvic trauma to be hemorrhage and sepsis, vascular and rectal injury in a series of 28 patients. The American Association for the Surgery of Trauma (AAST) has developed a grading system for organ injury severity; the severity of bladder injuries is measured by an AAST organ injury severity scale (Table) (2).

The European Association of Urology (EAU) guidelines have classified bladder injuries into two groups: Noniatrogenic trauma and iatrogenic trauma (3). Noniatrogenic trauma is divided into blunt and penetrating; iatrogenic trauma is divided into external, internal and foreign body. For intraperitoneal bladder injuries, both the EAU and American Urological Association guidelines recommend surgical repair to prevent peritonitis.

In this particular patient, the exploration was indicated by the general surgeons due to an intraabdominal penetrating injury. The bladder was intact radiologically,

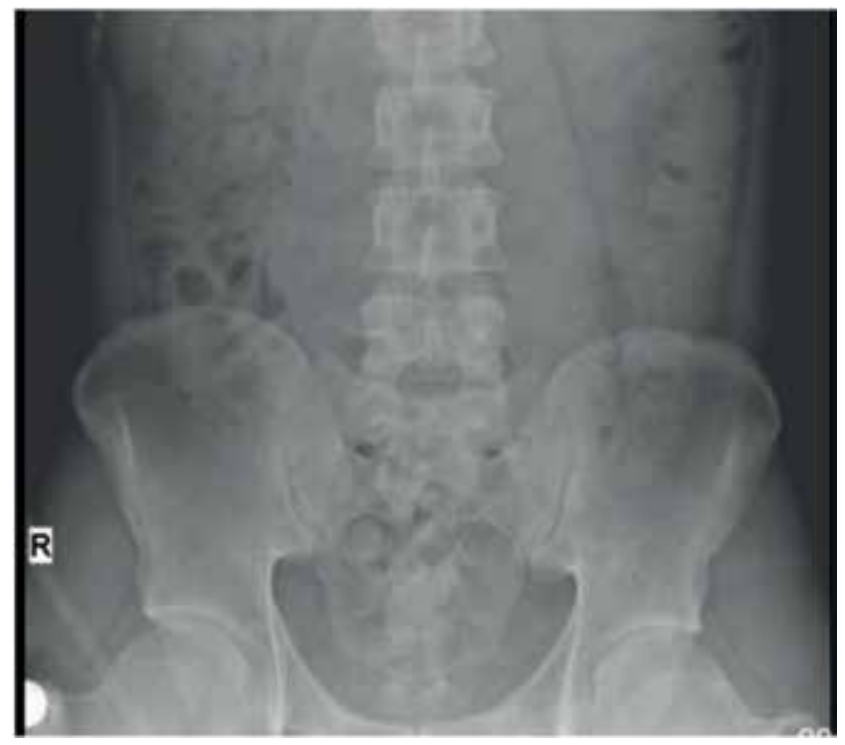

Figure 3. Pelvic radiography after voiding bullet

\begin{tabular}{|l|l|l|}
\hline \multicolumn{2}{|c|}{ Table. American Association for the Surgery of Trauma organ injury severity scale for bladder trauma } \\
\hline Grade* & Injury & Description \\
\hline I & $\begin{array}{l}\text { Haematoma } \\
\text { Laceration }\end{array}$ & $\begin{array}{l}\text { Contusion, intramural haematoma } \\
\text { Partial thickness }\end{array}$ \\
\hline II & Laceration & Extraperitoneal bladder wall laceration $<2 \mathrm{~cm}$ \\
\hline III & Laceration & Extraperitoneal $(>2 \mathrm{~cm}$ ) or intra-peritoneal $(<2 \mathrm{~cm})$ bladder wall lacerations \\
\hline IV & Laceration & Intraperitoneal bladder wall laceration $>2 \mathrm{~cm}$ \\
\hline V & Laceration & Laceration extending into bladder neck or ureteral orifice (trigone) \\
\hline \multirow{2}{*}{${ }^{2}$ Advance one grade for multiple lesions up to grade III } \\
\hline
\end{tabular}


preoperatively. A urologic consultation was asked because the bullet could not be found intraabdominally. Intraoperatively, no sign of a bladder injury or a perforation could be demonstrated. However, the bullet was voided spontaneously 30 days after the surgery. In the literature, there are case reports of patients voiding the bullet spontaneously, but in most of them, the patients were not explored surgically $(4,5)$. This case shows that in spite of a thorough pelvic surgical exploration, the bullet may not be visible or palpable if the bladder wall is not palpated with the intention of finding a bullet between its' layers; for it may resign inside the bladder wall leaving the mucosa intact inside, and the serosa without any obvious sign of injury outside. Therefore, it is mandatory to palpate and feel all the layers of the detrusor muscle and the bladder wall with the intention of looking for a bullet between the layers if it could not be found elsewhere.

Most reasonable explanation for this event is that; the bullet was covered by the edema of the detrusor and the serosa and it was not visible during the surgery. After some time and bladder contractions, the bullet eroded into the bladder cavity and was spontaneously expulsed through the urethra. Due to the edema produced secondary to the trauma during the passage of the bullet, the patient experienced transient urinary retention which resolved in a few days.

\section{Conclusion}

During a surgery secondary to a gunshot wound, it is mandatory to explore all the layers of the bladder wall, also by palpation, if no sign is relevant by inspection for the bullet may resign between the layers of the bladder wall and may not be seen by only inspection.

\section{Ethics}

Informed Consent: It was taken.

Peer-review: External and Internal peer-reviewed.

\section{Authorship Contributions}

Surgical and Medical Practices: Yasin Ceylan, Zafer Kozacıoğlu. Concept: Yasin Ceylan, Zafer Kozacıoğlu

Design: Yasin Ceylan, Zafer Kozacıoğlu. Data Collection or Processing: Volkan Şen, İbrahim Küçüktürkmen, Bülent Günlüsoy, Tansu Değirmenci. Analysis or Interpretation: Yasin Ceylan, Zafer Kozacıoğlu. Literature Search: Volkan Şen, Ibrahim Küçüktürkmen, Bülent Günlüsoy, Tansu Değirmenci. Writing: Yasin Ceylan, Volkan Şen.

Conflict of Interest: No conflict of interest was declared by the authors.

Financial Disclosure: The authors declared that this study received no financial support.

\section{References}

1. Arthurs Z, Kjorstad R, Mullenix P, Rush RM Jr, Sebesta J, Beekley $A$. The use of damage-control principles for penetrating pelvic battlefield trauma. Am J Surg 2006;191:604-9.

2. Moore EE, Cogbill TH, Jurkovich GJ, et al. Organ injury scaling. III: Chest wall, abdominal vascular, ureter, bladder, and urethra. J Trauma 1992;33:337-9.

3. Lynch TH, Martínez-Piñeiro $L$, et al. EAU guidelines on urological trauma. Eur Urol 2005;47:1-15.

4. Friedman AA, Trinh QD, Kaul S, Bhandari A. Complete endoscopic management of a retained bullet in the bladder. Can Urol Assoc J 2013;7:143-5.

5. Kiliç D, Kilinç F, Ezer A, Guvel S. Spontaneous expulsion of a bullet via the urethra. Int J Urol 2004;11:576-7. 